\title{
Influence of Media Composition and Genotype on Potato (Solanum tuberosum L.) Microtuberization
}

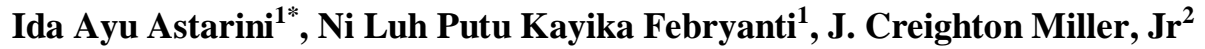 \\ Diterima 22 Januari 2021/Disetujui 26 April 2021
}

\begin{abstract}
Potato (Solanum tuberosum L.) is one of the most important crops in the world. Providing virus free, early generation seeds is a major potato production problem. Production of early generation potato minitubers under greenhouse conditions still have the risk of insect contamination and virus transmission. In vitro microtuberization provides an alternative method in the production of clean seed. The purpose of this study was to determine the optimum media for microtuber production in four potato genotypes, i.e. AOTX98202-1RU, ATX9202-3RU, ATTX98468-5R/Y and ATTX98518-5P/Y. The four genotypes were cultured in Murashige and Skoog (MS) media with addition of 6\% sucrose, with or without $2 \mathrm{~g} \mathrm{~L}^{-1}$ phytagel, and with or without $10 \mathrm{mg} \mathrm{L}^{-1}$ kinetin. Two nodal cuttings were cultured in each vessel with five replications. Culture were incubated with 16 h/day light and $23{ }^{\circ} \mathrm{C}$ for two weeks, and then moved to a cooler growth room at $16{ }^{\circ} \mathrm{C}$ for two weeks, followed by incubation in the dark at $16^{\circ} \mathrm{C}$ for 6 weeks, and observed for 10 weeks. Result shows that genotypes responded differently to the media. $2 \mathrm{~g} \mathrm{~L}^{-1}$ phytagel $+10 \mathrm{mg} \mathrm{L}^{-1}$ kinetin treatment (T4) was an effective treatment to enhance microtuber growth in genotype ATTX98468-5R/Y and ATTX985185P/Y. ATTX98468-5R/Y in T4 media produced the highest number of microtubers $(4.2$ microtubers/vessel), while ATTX98518-5P/Y produced the heaviest average fresh weight (363.6 mg). Results suggest the importance of developing specific protocols for each genotype for optimum production of microtubers.
\end{abstract}

Keywords: genotype, in vitro, kinetin, microtuber, phytagel

\begin{abstract}
ABSTRAK
Kentang (Solanum tuberosum L.) adalah salah satu komoditi pangan penting di dunia. Penyediaan benih kentang generasi awal yang bebas penyakit sistemik virus merupakan masalah utama dalam pembudidayaan kentang. Produksi benih kentang generasi awal berupa umbi mini di rumah kaca masih memiliki resiko kontaminasi oleh penyakit virus. Teknik produksi umbi mikro secara in vitro dapat menjadi metode alternatif untuk produksi benih sumber. Tujuan penelitian ini adalah untuk menentukan media yang optimum dalam produksi umbi mikro pada empat genotipe kentang, yaitu AOTX98202-1RU, ATX9202-3RU, ATTX98468-5R/Y dan ATTX98518-5P/Y. Keempat genotipe dikulturkan pada media Murashige and Skoog (MS) dengan tambahan 6\% sukrosa, dengan atau tanpa $2 \mathrm{~g} \mathrm{~L}^{-1}$ phytagel, dan dengan atau tanpa $10 \mathrm{mg} \mathrm{L}^{-1}$ kinetin. Stek dua buku dikulturkan pada tiap botol kultur, masing - masing dengan lima ulangan. Kultur diinkubasi selama dua minggu pada suhu $23^{\circ} \mathrm{C}$ dengan fotoperiode 16 jam terang/hari, lalu suhu $16{ }^{\circ} \mathrm{C}$ selama 2 minggu dengan fotoperiode $16 \mathrm{jam}$ terang/hari, dan suhu $16^{\circ} \mathrm{C}$ dalam ruang gelap selama 6 minggu, dan diamati selama 10 minggu. Hasil penelitian menunjukkan bahwa tiap genotipe memiliki respon yang berbeda terhadap media. Perlakuan $2 \mathrm{~g} \mathrm{~L}^{-1}$ phytagel $+10 \mathrm{mg} \mathrm{L}^{-1}$ kinetin (T4) merupakan media yang efektif untuk mendorong pertumbuhan umbi mikro pada genotipe ATTX98468-5R/Y dan ATTX98518-5P/Y. Genotipe ATTX98468-5R/Y pada media T4 menghasilkan umbi mikro terbanyak (4.2 umbi mikro/botol), sedangkan ATTX98518-5P/Y menghasilkan rata-rata berat umbi tertinggi (363.6 mg). Hasil penelitian menunjukkan pentingnya untuk mengembangkan protokol khusus untuk tiap genotipe agar mendapatkan produksi umbi mikro yang optimal.
\end{abstract}

Kata kunci: genotipe, in vitro, kinetin, phytagel, umbi mikro

\footnotetext{
${ }^{1}$ Biology Study Program, Faculty of Mathematics and Natural Sciences, Udayana University Jl. Kampus Bukit Jimbaran, 80361, Denpasar, Indonesia.

${ }^{2}$ Department of Horticultural Sciences, College Station, Texas A\&M University

Horticulture/Forest Science Bldg, Suite 202, 2133 TAMU, 495 Horticulture Street, College Station.

E-mail : iaastarini@unud.ac.id (*penulis korespondensi)
} 


\section{INTRODUCTION}

Potato (Solanum tuberosum L.) is one of the most important crops, ranks in fourth after wheat, rice and maize grown all over the world (Zhang et al., 2017). At present, potato growing areas in Indonesia ranging between 60000 and 70000 ha with a total production of about $1.2-1.3$ million tons per year. The Indonesian Agricultural Research Development Agency (IAARD) considered potato as a priority crop to develop, because of its potential as an alternative source of carbohydrates in food diversification and for export markets (Gunadi et al., 2017; Putra et al., 2019).

Providing virus free, early generation seed is the major potato production problem in developing countries. In Indonesia, mostly use of late generation seed decrease potato productivity less than 20 ton $\mathrm{ha}^{-1}$. In vitro microtuberization provides an alternative method in the production of clean nuclear seed in potato (Hoque, 2010). Microtubers have advantages in terms of diseases free, storage, and transportation. It can be directly sown into the field and can be produced all the year, also have similar morphological and biochemical characteristics. Therefore, mass production of potato microtubers to be the key of potato production in the world (Gudeva et al., 2016). Important factor for in vitro growth and microtuber production were genotype use, media component such as carbohydrate source, growth regulators (Hossain et al., 2017; Ali et al., 2018; Teng et al., 2018).

Uses of kinetin as growth regulator in microtuberization have been reported in a number of studies. Kinetin significantly stimulated tuber formation in both wild type potato and D-12 cultivar (Aksenova et al., 2009). Nasiruddin et al. (2013) reported that kinetin is more effective than BA for microtubers production. Garcia et al. (2019) described that the independent action of kinetin in potato microtuberization increased number and weight, diameter in Alpha genotype.

In addition to growth hormones, type of media is also important for microtuberization efficiency (Kumlay, 2014; Yagiz et al., 2020). Liquid media was reported has a significant effect on plant growth and efficient in vitro microtubers production
(Mbiyu et al., 2012; Dhital and Lim, 2012). Solid media was used widely in many studies (Arregui et al., 2003; Hossain et al., 2017; Borna et al., 2019). Common solid media uses include agar, Difco Bacto-agar, gellan gum, guar gum and phytagel (Arregui et al., 2003; Hussien et al., 2014).

Phytagel is solidifying agent that produced from a bacterial substrate that is composed of rhamnose, glucose and glucuronic acid. Phytagel produce clear culture media and colorless growth matrix for plants (Sigma-Aldrich, 2019; Jacques et al., 2020). Arregui et al. (2003) reported that phytagel can promote more rapid tuberization and larger microtubers compared to medium containing Difco Bacto-agar when cultured in medium with kinetin and placed in the dark or under an 8-h photoperiod. Phytagel also increased in vitro multiplication rate in majority of Indian potato cultivars (Sharma et al., 2011). The aims of experiment was to investigate the ability to produced microtubers of four potato genotypes by using combination of phytagel and kinetin.

\section{MATERIAL AND METHODS}

\section{Plant material}

The experiment used potential breeding lines from potato breeding program, Horticulture Department, Texas A\&M University, i.e. AOTX98202-1RU, ATX92023RU, ATTX98468-5R/Y and ATTX98518$5 \mathrm{P} / \mathrm{Y}$. Plant materials were four weeks after planting in vitro potato shoot, cultured in Tissue Culture Laboratory, Horticulture Department, Texas A\&M University, College Station, Texas, USA. The plant growth regulator used for this experiment was kinetin, and Phytagel ${ }^{\mathrm{TM}}$ Sigma Chemical Co. (St. Louis, MO, USA) as the gelling agent.

\section{In vitro production of microtubers}

Two nodal cuttings $(0.5-1.0 \mathrm{~cm})$ of four potato genotypes were cultured in each vessel with media consisted of Murashige and Skoog (MS) salts and vitamins (Murashige and Skoog 1962) with $6 \%$ of sucrose. The $\mathrm{pH}$ of the media was adjusted to 5.8. Cultures were maintained with $16 \mathrm{~h} \mathrm{day}^{-1}$ light and $23{ }^{\circ} \mathrm{C}$ for two weeks, and then moved to a cooler growth 
room at $16{ }^{\circ} \mathrm{C}$ for two weeks, followed by incubation in the dark at $16{ }^{\circ} \mathrm{C}$ for 6 weeks.

\section{Experimental design and data analysis}

The experiment was conducted using complete randomized design (CRD) with two factors, i.e. genotype and media. Four genotypes trialed were AOTX98202-1RU (G1), ATX9202-3RU (G2), ATTX984685R/Y (G3), ATTX98518-5P/Y (G4). The media combination were no phytagel or kinetin (T1), $2 \mathrm{~g} \mathrm{~L}^{-1}$ phytagel and no kinetin (T2), no phytagel and $10 \mathrm{mg} \mathrm{L}^{-1}$ kinetin (T3), $2 \mathrm{~g} \mathrm{~L}^{-1}$ phytagel and $10 \mathrm{mg} \mathrm{L}^{-1}$ kinetin (T4). Each treatment combination consists of five replicates. Each replicate consisted of one culture vessel with two plantlets on each vessel.

Observation were recorded until 10 weeks i.e. total microtuber produced/vessel and average fresh weight of microtube. Microtubers were harvested from the stems. Callus formation was also recorded. After harvest microtubers were then placed into falcon tubes for storage. Data were analysed using Analysis of Variance on SPSS Statistical and means of all treatments and cultivars were compared by Duncan's Multiple Range Test (DMRT) at $5 \%$ level of significance $(\mathrm{P} \leq 0.05)$.

\section{RESULT AND DISCUSSION}

The results showed that all variables (genotypes, media combination and interaction between genotype $\mathrm{x}$ media) were significantly different (Table 1). Genotype and treatment of phytagel and kinetin were significantly affected the number of microtuber/vessel produced and average fresh weight of microtuber. Differences in the number of microtuber and average fresh weight between treatments depended on the genotype.

\section{Number of microtuber produced}

All treatments induced the formation of microtubers, except for genotype in $\mathrm{T} 1$ media (Table 2). The highest total number of microtuber/ vessel was ATTX98468-5R/Y in T4 media with 4.2 microtubers/vessel (Figure 1A). The AOTX98202-1RU genotype produced the highest microtubers when cultured in T4 treatment media with 2.0 microtubers/vessel, ATX9202-3RU genotype in $\mathrm{T} 2$ and $\mathrm{T} 3$ treatment media with 2.8 microtubers/vessel while the ATTX98518$5 \mathrm{P} / \mathrm{Y}$ genotype was in $\mathrm{T} 2$ and $\mathrm{T} 3$ media with 2.4 microtubers/vessel. No microtuber produced in ATTX98518-5P/Y in T1 media (Figure 1B). High concentrations of kinetin also induced callus formation on AOTX98202-1RU (Fig. 1C).

\section{Average fresh weight of microtubers}

A comparison among treatments indicated that genotype ATTX98518-5P/Y in T4 media produced heaviest microtubers (363.6 mg). Genotype AOTX98202-1RU produced heaviest microtubers in $\mathrm{T} 2$ media (344.4 mg), genotype ATX9202-3RU produced heaviest microtubers in media $\mathrm{T} 1$ (287.8 mg), ATTX98468-5R/Y produced heaviest microtubers in $\mathrm{T} 1 \mathrm{media}(359.0 \mathrm{mg})$. As a result, the heaviest average weight was ATTX98518-5P/Y in media with addition of 2 $\mathrm{g} \mathrm{L}^{-1}$ phytagel $+10 \mathrm{mg} \mathrm{L}^{-1}$ kinetin (Table 2).

Table 1. The mean square value of microtuber growth affected by treatment of genotypes and Kinetin, Phytagel after 10 weeks of incubation.

\begin{tabular}{cccc}
\hline \multicolumn{3}{c}{ Mean square values } \\
\hline Source of variation & df & $\begin{array}{c}\text { Number of } \\
\text { microtuber/vessel }\end{array}$ & $\begin{array}{c}\text { Average microtuber fresh } \\
\text { weight (mg) }\end{array}$ \\
\hline Genotypes (G) & 3 & $8.98^{*}$ & $33842.53^{*}$ \\
\hline Treatment (T) & 3 & $5.45^{*}$ & $73179.98^{*}$ \\
\hline G x T & 9 & $4.27^{*}$ & $127293.87^{*}$ \\
\hline Error & 64 & & \\
\hline
\end{tabular}

*Significant at $5 \%$ and $1 \%$. 


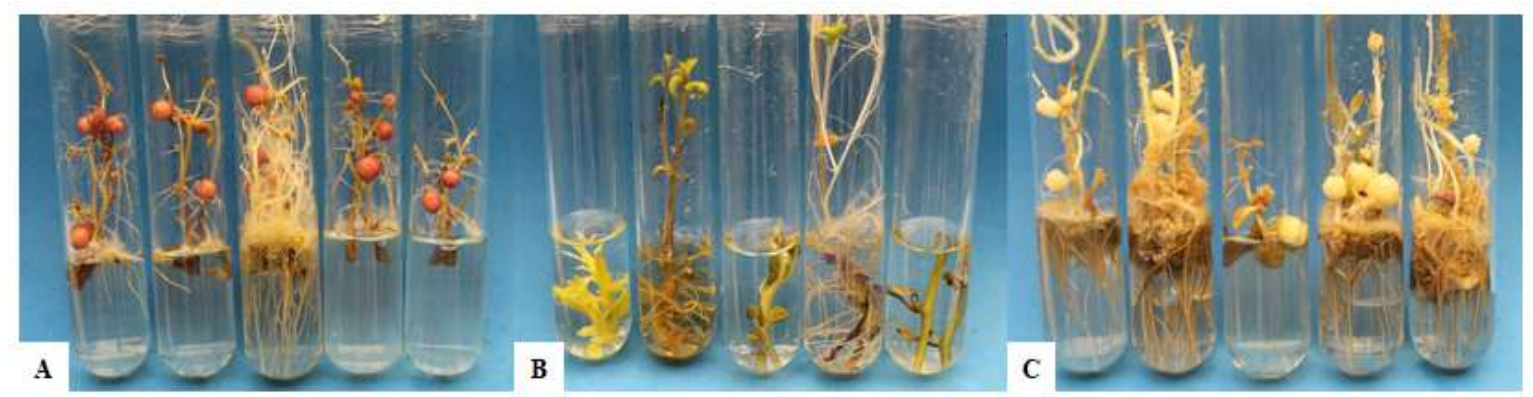

Figure 1. Microtuber production in potato. A. Genotype ATTX98468-5R/Y in T4 media. B. No microtuber produced in genotype ATTX98518-5P/Y in T1 media. C. callus production on AOTX98202-1RU.

Table 2. Effect of phytagel, genotype and kinetin treatment on number of microtubers/vessel and average fresh weight of microtubers of four potato genotypes.

\begin{tabular}{|c|c|c|c|}
\hline Genotype & Treatment & $\begin{array}{c}\text { Number of microtubers } \\
\text { produced/vessel }\end{array}$ & $\begin{array}{l}\text { Average fresh weight } \\
(\mathrm{mg})\end{array}$ \\
\hline \multirow[t]{4}{*}{ AOTX98202-1RU (G1) } & $\mathrm{T} 1$ & $1.4^{\mathrm{fg}}$ & $83.0^{\mathrm{cd}}$ \\
\hline & $\mathrm{T} 2$ & $1.8^{\mathrm{fg}}$ & $344.4^{\mathrm{ab}}$ \\
\hline & $\mathrm{T} 4$ & $1.0^{\mathrm{g}}$ & $277.0^{\mathrm{ab}}$ \\
\hline & $\mathrm{T} 4$ & $2.0^{\mathrm{def}}$ & $242.0^{\mathrm{abc}}$ \\
\hline \multirow[t]{4}{*}{ ATX9202-3RU (G2) } & $\mathrm{T} 1$ & $1.4^{\mathrm{fg}}$ & $287.8^{\mathrm{ab}}$ \\
\hline & $\mathrm{T} 2$ & $2.8^{\mathrm{bcd}}$ & $258.0^{\mathrm{ab}}$ \\
\hline & $\mathrm{T} 3$ & $2.8^{\mathrm{bcd}}$ & $231.2^{\mathrm{abc}}$ \\
\hline & $\mathrm{T} 4$ & $2.6^{\mathrm{cde}}$ & $232.4^{\mathrm{abc}}$ \\
\hline \multirow[t]{4}{*}{ ATTX98468-5R/Y (G3) } & $\mathrm{T} 1$ & $3.6^{\mathrm{ab}}$ & $359.0^{\mathrm{ab}}$ \\
\hline & $\mathrm{T} 2$ & $3.0^{\mathrm{bc}}$ & $200.8^{\mathrm{abc}}$ \\
\hline & $\mathrm{T} 3$ & $1.2^{\mathrm{fg}}$ & $201.6^{\mathrm{abc}}$ \\
\hline & $\mathrm{T} 4$ & $4.2^{\mathrm{a}}$ & $168.0^{\mathrm{bc}}$ \\
\hline \multirow[t]{4}{*}{ ATTX98518-5P/Y (G4) } & $\mathrm{T} 1$ & $0^{\mathrm{h}}$ & $0^{\mathrm{d}}$ \\
\hline & $\mathrm{T} 2$ & $2.4^{\text {cde }}$ & $229.9^{\mathrm{abc}}$ \\
\hline & $\mathrm{T} 3$ & $2.4^{\text {cde }}$ & $292.0^{\mathrm{ab}}$ \\
\hline & $\mathrm{T} 4$ & $2.0^{\mathrm{def}}$ & $363.6^{\mathrm{a}}$ \\
\hline
\end{tabular}

$\operatorname{DMRT}(\mathrm{P} \leq 0.05)$

Note: In each column, values followed by different letters are statistically significantly different at 5\% level of significance by DMRT. T1 = no phytagel or kinetin, $\mathrm{T} 2=2 \mathrm{~g} \mathrm{~L}^{-1}$ phytagel and no kinetin, $\mathrm{T} 3=$ no phytagel and $10 \mathrm{mg} \mathrm{L}^{-1}$ kinetin, $\mathrm{T} 4=2 \mathrm{~g} \mathrm{~L}^{-1}$ phytagel and $10 \mathrm{mg} \mathrm{L}^{-1}$ kinetin. 


\section{Discussion}

Microtubers are usually induced on medium containing growth regulator. Growth regulator can create physiological imbalance causing formation of microtubers and induce acids in the microtuberization medium (Nistor et al., 2013). It was found in this experiment, the highest number of microtuber/vessel produced was on genotype ATTX98468-5R/Y cultured in media T4. The heaviest average weight was ATTX98518-5P/Y also cultured in media T4. Addition of $10 \mathrm{mg} \mathrm{L}^{-1}$ kinetin has positive effect on microtuberization and increased total microtuber/vessel produced. Romanov et al. (2000) and Sota et al. (2020) reported that kinetin induced cell elongation and tuberization. Kinetin is needed to stimulate the process of translocation of sugar into developing tubers. The amount of starch required to form microtubers appears to depend on the amount of sucrose available in the tissue culture medium. Thus, higher sucrose together with kinetin stimulates microtuber formation. Kinetin is thought to have a stimulatory effect by increasing starch synthetase activity and suppressing starch hydrolase activity (Mohamed and El-Sherif, 2014). Momena et al. (2014) reported that the use of kinetin in microtubers production media increased the microtuber formation rate of potato cultivars Diamond. Ali et al (2018) also revealed that addition of kinetin in culture media induced earlier microtuber formation.

High concentration of kinetin induced callus formation on genotype AOTX982021RU. Kumar et al. (2014) explained that in theory, equal amounts of auxin and cytokinin promote callus induction. However, in practice, this can vary due to variations in the endogenous levels of phytohormones in individual plants. Genotype AOTX98202$1 \mathrm{RU}$ may have high level of endogenous auxin in which together with addition on kinetin in the media resulted in callus induction.

Successful plant tissue culture depends on properties of growth medium, especially the mechanical property. Phytagel belongs to a complex fluid (Zhou et al., 2019). The addition of phytagel in media clearly support number of microtubers and weight of microtubers produced. This may be due to present of glucose in phytagel together with sucrose in the media, induced microtuber production. Phytagel was commonly added at
$0.5 \%-2.0 \%$ for optimum plant growth in vitro (Zhou et al., 2019). In this experiment, phytagel provided support for the shoots to grow upward and performed photosynthesis in the first four weeks, followed by microtuber formation for six weeks. Previous study by Veramendi et al. (1997) reported that phytagel allowed faster in vitro tuberization and larger tubers of potato than those cultured in Difco Bacto-agar. Phytagel as compared to agar may change the tissue sensitivity to cytokinins such as kinetin. Nevertheless, the in vitro development is dependent on the explants and the medium interaction.

Sucrose concentration used in this study was $6 \%$, and the optimum sucrose concentration has been reported between $6 \%$ and $8 \%$ for tuber induction (Aslam and Iqbal, 2010; Hossain et al., 2017). In plant tissue culture, most plant requires an exogenous carbohydrates source because limited photosynthesis occurred in vitro (Lian et al., 2014). Tuberization is known to be regulated by carbohydrates availability such as sucrose, which is the transported form of sugar required for starch synthesis (Abelenda et al., 2019). The amount of sugar were positively correlated with the size of potato. The result of this experiment showed that three genotypes (AOTX98202-1RU, ATX9202-3RU and ATTX98468-5R/Y) produced microtubers even in media without addition of plant growth regulators. Similar results from Aksenova et al. (2009) found that microtubers can be induced even without using growth regulator. Garcia et al. (2019) also reported that the heaviest weight of microtuber in potato cultivar Atlantic was in a growth regulator-free culture medium. Uses of media without plant growth regulators revealed that the genotype has an innate capacity to produce microtubers. Apart from effect of growth regulator, microtuberization also depends on plant genotype and amount of sucrose in culture medium (Romanov et al., 2000).

In this experiment, for microtuber induction incubated in the dark for six week successfully induced microtuber formation. Same results was found on Ali et al. (2018), who reported that dark condition provides better response on microtuberization as compared to light condition. Potatoes are known as short day plant, so that dark photoperiod would affect tuber formation. In 
such condition, in vitro potato shoots will change its growth direction from upper to lower meristem, including micotuber formation (Dwiati and Anggorowati, 2011).

Results of this study suggested the importance of developing specific protocols for each genotype for optimum microtuber production, as each genotype response differently to media (Table 2). This experiment did not consider the effects of the hormone and phytagel on microtuber dormancy. How the microtubers respond to long term storage, reintroduction in vitro, greenhouse conditions, and could be directly planting microtubers in the field will have required further investigation.

In the future, mass production of microtuber could be a promising option to provide good quality, disease free seed potatoes. This in vitro technique increase rate of multiplication process, resulting in more seed potato can be produced in shorter time, all year round and economically cheaper than other method (Herrea-Isidron et al., 2021). Other advantage include easy storage and transportation (Hossain et al., 2017).

\section{CONCLUSION}

The conclusion, $\mathrm{T} 4$ treatment $\left(2 \mathrm{~g} \mathrm{~L}^{-1}\right.$ phytagel $+10 \mathrm{mg} \mathrm{L}^{-1}$ kinetin), was effective to enhance microtuber production in genotype ATTX98468-5R/Y and ATTX98518-5P/Y. ATTX98468-5R/Y cultured in medium with T4 treatment produced the highest microtubers/vessel, and ATTX98518-5P/Y produced the heaviest fresh weight.

\section{ACKNOWLEDGEMENTS}

We would like to express our sincere appreciation to AMINEF for funding support to Ms. Ida Ayu Astarini to undertake Fulbright Senior Research Program in Texas A\&M University, College Station, Texas, USA. Thanks also to Angel Chappell, Douglas Scheuring and Sean Thompson for technical guidance.

\section{REFERENCES}

Abelenda, J.A., S. Bergonzi, M. Oortwijn, S. Sonnewald, M. Du, R.G. Visser, U. Sonnewald, C.W. Bachem. 2019. Source-sink regulation is mediated by interaction of an FT homolog with a sweet protein in potato. Curr. Biol. 29: 1178-1186.

Ali, S., N. Khan, F. Nouroz, S. Erum, W. Nasim. 2018. Effects of sucrose and growth regulators on the microtuberization of cip potato (Solanum tuberosum) germplasm. Pak. J. Bot. 52(2): 763-768.

Aksenova, N.P., T.N. Konstantinova, V.N. Lozhnikova, S.A. Golyanovskaya, L.I. Sergeeva. 2009. Interaction between day length and phytohormones in the control of potato tuberization in the in vitro culture. Russ. J. Plant Physiol. 56: 454-461.

Doi: https://doi.org/10.1134/S1021443709 040037

Aslam, A., J. Iqbal. 2010. Combined effect of cytokinin and sucrose on in vitro tuberization parameters of two cultivars i.e., Diamant and Red Norland of potato (Solanum tuberosum). Pak. J. Bot. 42: 10931102.

Arregui, L.M., J. Veramendi, A.M. MingoCastel. 2003. Effect of gelling agents on in vitro tuberization of six potato cultivars. Am. J. Potato Res. 80: 141144.

Doi: https://doi.org/10.1007/BF02870213

Borna, R.S., M.I. Hoque, R.H. Sarker. 2019. In vitro microtuber induction and regeneration of plantlets from microtuber discs of cultivated potato (Solanum tuberosum L.). Plant Tiss. Cult. Biotech. 29: 63-72. Doi: https://doi.org/10.3329/ptcb.v29i1.41 979 
Dhital, S.P., H.T. Lim. 2012. Microtuberization of potato (Solanum tuberosum L.) as influenced by supplementary nutrients, plant growth regulators, and in vitro culture conditions. Potato Res. 55: 97-108. Doi: https://doi.org/10.1007/s11540012-9212-y

Dwiati, M., S. Anggorowati. 2011. Induction of in vitro cuture of potato micro tuber by using alar and dark photoperiod application. Agrivita 33(1): 47-52.

García, J.A.G., J.B.A. Bolaños, F.S. Campos, R.O. Rodríguez. 2019. Effect of two cytokinins and a growth inhibitor on the in vitro tuberization of two genotypes of Solanum tuberosum L. cvs. Atlantic and Alpha. Uniciencia 22: 1-12. Doi: https://doi.org/10.15359/ru.33-2.1

Gudeva, K.L., F. Trajkova, I. Stojkova. 2016. The effect of plant growth regulators and sucrose on microtuberization of potato (Solanum tuberosum L.). Roman. Agric. Res. 33: 1-7.

Gunadi, N., A. Pronk, A.K. Karjadi, L. Prabaningrum, T.K. Moekasan. 2017. Effect of selection methods on seed potato quality. vegIMPACT report 37. www.edepot.wur.nl/415365

Hoque, M.E. 2010. In vitro tuberization in potato (Solanum tuberosum L.). Plant Omics. 3: 7-11.

Hossain, M.S., M.M. Hossain, M.M. Haque, T. Hossain, M. Zakaria, M.D. Sarkar. 2017. Varietal performance of potato on induction and development of microtuber in response to sucrose. Annals Agric. Sci. 62: 75-81. Doi: https://doi.org/10.1016/j.aoas.2017.0 5. 002

Herrera-Isidron, L., E. Valencia-Lozano, P.Y. Rosiles-Loeza, M. G. RoblesHernández, A. Napsuciale-Heredia, J.L. Cabrera-Ponce. 2021. Gene expression analysis of microtubers of potato Solanum tuberosum L. induced in cytokinin containing medium and osmotic stress. Plants. 10(876): 1-15. Doi:https://doi.org/10.3390/plants100 50876

Hussien, F.A., M.A. Osman, T.I.M. Idris. 2014. The influence of liquid media support, gelling agents and liquid overlays on performance of in vitro cultures of ginger (Zingiber officinale). Int. J. Sci. Res. Public. 4: $1-5$.

Jacques, C.N., A.K. Hulbert, S. Westenskow, M.M. Neff. 2020. Production location of the gelling agent Phytagel has a significant impact on Arabidopsis thaliana seedling phenotypic analysis. PLOS ONE. 15(5): e0228515 Doi: https://doi.org/10.1371/journal.pone. 0228515

Kumar, V., D. Rashmi, M. Banerjee. 2014. Callus induction and plant regeneration in Solanum tuberosum $\mathrm{L}$. cultivars (Kufri Chipsona 3 and MP97/644) via leaf explants. Int. Res. J. Biol. Sci. 3(6): 66-72.

Kumlay, A. 2014. Combination of the auxins NAA, IBA and IAA with GA3 improves the commercial seed-tuber production of potato (Solanum tuberosum L.) under in vitro conditions. BioMed. Res. Int. 1-7. Doi:https://doi.org/10.1155/2014/439 259

Lian, M.L., X.C. Piao, S.Y. Park. 2014. Mass production of Lilium bublets in bioreactors. In: Paek KY, Murthy H, Zhong JJ (eds) Production of biomass and bioactive compounds using bioreactor technology. Dordrecht Heidelberg New York. Springer, London.

Mbiyu, M., J. Muthoni, J. Kabira, C. Muchira, P. Pwaipwai, J. Ngaruiya, J. Onditi, S. Otieno. 2012. Comparing liquid and solid media on the growth of plantlets from three Kenyan potato cultivars. Am. J. Exp. Agric. 2: 81-89. 
Mohamed, A.E., M.H. El-Sherif. 2014. A novel in vitro hydroponics culture system for potato (Solanum tubersum L.) microtuber production. J. App. Sci. Res. 10: 11-217.

Momena, K., R. Adeeba, H. Mehraj, A.F.M.J. Uddin, S. Islam, L. Rahman. 2014. In vitro microtuberization of potato (Solanum tuberosum 1.) cultivar through sucrose and growth regulator. J. Biosci. Agric. Res. 2:76-82. Doi: https://doi.org/10.18801/jbar.020214. 22

Murashige, T., F. Skoog. 1962. A revised medium for rapid growth and bioassays with tobacco tissue culture. Plant. Physiol. 15: 473-497. Doi: https://doi.org/10.1111/j.13993054.1962.tb08052.x

Nasiruddin, M., Maliha, H. Armin, M.R. Karim, M.M. Hossain. 2013. Potato germplasm innovation through microtuberization technique. Int. J. Biosci. 3: 135-141.

Putra, A.A., A. Maharijaya, Sobir. 2019. Keragaan dan produksi umbi G2 kentang menggunakan sumber benih yang berbeda. J. Hort. Indonesia 10(1): 27-35. Doi: https://doi.org/10.29244/jhi.10.1.2735

Romanov, G.A., N.P. Aksenova, T.N. Konstantinova, S.A. Golyanovskaya, J. Kossman, L. Willmitzer. 2000. Effect of Indole-3-Acetic Acid and Kinetin on tuberization parameters of different cultivars and transgenic lines of potato in vitro. Plant Growth Reg. 32: 245-251. Doi: https://doi.org/10.1023/A:101077151 0526

Sharma, S., E.P. Venkatasalam, R. Patial, J. Latawa, S. Singh. 2011. Influence of gelling agents and nodes on the growth of potato microplant. Potato J. 38: 41-46.
Sigma-Aldrich. 2019. Product information phytagel. www.sigmaldrich.com

Sota, V., S. Bekheet, E. Kongjika. 2020. Effect of growth regulators on micropropagation and in vitro tuberization of Solanum tuberosum L. cv. Vermosh. South West. J. Hort. Biol. Env. 11: 67-81.

Teng, Y., Z. Yan, J.T. Guo, Y.L. Gao, K.H. Li. 2019. Acid pretreatment improves microtuberization of potato plantlets. In Vitro Cell. Dev. Biol. 55:36-43. Doi: https://doi.org/10.1007/s11627018-09950-6

Veramendi, J., M. J. Villafranca, V. Sota, A.M. Mingo-Castel. 1997. Gelrite as an alternative to agar for micropropagation and microtuberization of Solanum tuberosum L. cv. Baraka. In Vitro Cell. Dev. Biol. Plant. 33:195-199. Doi: https://doi.org/10.1007/s11627997-0021-y

Yagiz, A.K., C. Yavuz, C. Tarim, U. Demirel, M.E. Caliskan. 2020. Effects of growth regulators, media and explant types on microtuberization of potato. Am. J. Potato Res. 97: 523-530. Doi: https://doi.org/10.1007/s12230-02009801-4

Zhang, H., F. Xu, Y. Wu, H. Hu, X. Dai. 2017. Progress of potato staple food research and industry development in China. J. Integ. Agric. 16: 2924-2932. Doi: https://doi.org/10.1016/S20953119(17)61736-2

Zhou, Y., J. Yan, B.Y. Xu, B.C. Wang. 2019. The study on mechanical properties of Phytagel medium. IOP Conf. Series: Earth Env. Sci. 346: 012089. Doi: https://doi.org/10.1088/17551315/346/1/012089 